\title{
IMMUNOMODULATORY ACTIVITY OF MUNTINGIA CALABURA L. FRUITS USING CARBON CLEARANCE ASSAY AND THEIR TOTAL FLAVONOID AND PHENOLIC CONTENTS
}

\author{
TANTI AZIZAH SUJONO ${ }^{1 *}$ IKA TRISHARYANTI DIAN KUSUMOWATI ${ }^{2}$, RIMA MUNAWAROH ${ }^{3}$
}

${ }^{1}$ Department of Pharmacology and Clinical Pharmacy, Faculty of Pharmacy, Universitas Muhammadiyah Surakarta, 57162, Surakarta, Indonesia . .'Department of Pharmaceutical Chemistry, Faculty of Pharmacy, Universitas Muhammadiyah Surakarta, 57162, Surakarta, Indonesia. ${ }^{3}$ Department of Pharmaceutical Biology, Faculty of Pharmacy, Universitas Muhammadiyah Surakarta, 57162, Surakarta, Indonesia. Email: tanti_azizah@ums.ac.id

Received: 23 November 2019, Revised and Accepted: 26 December 2019

\section{ABSTRACT}

Objective: Muntingia calabura L fruits have several advantages for health and can be consumed as alternative medicine. This study aims to evaluate the immunomodulatory activity of methanol extract (ME) and fractions of M. calabura L fruits against non-specific immune response in mice and its total phenolic and flavonoid contents.

Methods: This research using carbon clearance assay or phagocytosis method which was done on mice. Seventy male Swiss mice were divided into 14 groups. Mice were treated with ME, hexane fraction (HF), dichloromethane fraction (DF), and ethyl acetate fraction (EAF) of M. calabura L. orally at a dose of 50,100, and $200 \mathrm{mg} / \mathrm{kg}$ daily for 7 days. Zymosan with a dose of $15 \mathrm{mg} / \mathrm{kg}$ was used as a positive control and given intraperitoneally, and CMC Na was used as a negative control. On the $8^{\text {th }}$ day, mice were injected with carbon ink suspension intravenously and blood samples were taken at the minutes of $0,5,10,15,20$, and 30 . Furthermore, the transmittance was measured at $\lambda 675 \mathrm{~nm}$. The total phenolic content was measured using the Folin-Ciocalteu method, and flavonoid content was measured using the $\mathrm{AlCl}_{3}$ method.

Results: Zymosan, ME, and EAF of M. calabura L. at a dose of $200 \mathrm{mg} / \mathrm{kg}$ showed a strong immunostimulatory effect (phagocytic index $>1.5$ ) while the $\mathrm{HF}$ and DF groups showed that the higher doses decreased the phagocytic index. The total phenolic contents of ME, HF, DF, and EAF were 27.90, 11.11, 16.72 , and $30.11 \%$, respectively, while the flavonoid contents were $4.07,0.17,3.07$, and $1.86 \%$, respectively.

Conclusion: ME and EAF of M. calabura L. fruits have immunostimulatory activity.

Keywords: Muntingia calabura L., Phagocytic index, Carbon clearance assay, Immunomodulator.

(c) 2020 The Authors. Published by Innovare Academic Sciences Pvt Ltd. This is an open access article under the CC BY license (http://creativecommons. org/licenses/by/4. 0/) DOI: http://dx.doi.org/10.22159/ajpcr.2020.v13i2.36449

\section{INTRODUCTION}

Immunomodulators are natural or synthetic substances that can regulate the immune system's balance; these can be immunostimulant or immunosuppressant [1]. The function of the immune system is very important for the prevention and recovery from infectious diseases. Activation of the immune response contributes to reducing the risk of chronic disease [1]. Some evidence that food and plant intake modulates and activates immune function [2]. Nowadays, the interest of people to use herbal medicines as agents that can modulate the immune system in preventing infection is increasing. Groups of compounds such as flavonoids, polysaccharides, lactones, alkaloids, diterpenoids, and glycosides have been reported to be responsible for the immunomodulating activity of plants [2].

One of the plants that can be developed as an immunomodulator is Muntingia calabura L. that known as "Talok or Kersen" in Indonesia. M. calabura $\mathrm{L}$. is a source of antioxidants because it contains compound such as vitamin C (ascorbic acid), tocopherol, flavonoids, phenolic acid, and carotenoids [3]. M. calabura L. plants are known to have a variety of pharmacological activities including antidiabetic [4], anti-inflammatory [3], antirheumatic [5], antioxidants [6], and immunomodulators [7]. Based on some previous studies, compounds that have antioxidant activity also have immunomodulatory activities [8]. M. calabura L. is thought to have an immunomodulatory effect because they contain flavonoids. The content of flavonoids has many pharmacological activities including immunomodulators [9]. Most phenolic derivatives in plants affect non-specific immune responses mainly through increasing phagocytosis and lymphocyte and neutrophil proliferation [10]. The mechanism of the immunomodulatory effects of M. calabura L. has not been known.

The novelty of this research is that until now no one has examined the effect of immunomodulators with non-specific immune response parameters using carbon clearance methods from methanol extract (ME) of M. calabura L. and their fractions from non-polar to semipolar (hexane, dichloromethane, and ethyl acetate) fractions to find out which fraction is more effective as an immunostimulant.

Therefore, it is necessary to test the immunomodulatory activity of M. calabura L. on non-specific immune responses. This study used a carbon clearance test which is one of the important methods for evaluating the effects of immunomodulators of drugs and chemicals in plants [11]. This study aimed to evaluate the immunomodulatory activity of ME and fractions of M. calabura L. fruits against non-specific immune response in mice and determine its total phenolic and flavonoid contents.

\section{MATERIALS AND METHODS}

Materials

Methanol, hexane, dichloromethane (Merck), ethyl acetate, tween 80, carboxymethyl cellulose Na, Zymosan A (Sigma-Aldrich), Indian ink, gelatin, $\mathrm{NaCl} 0.9 \%$, Titriplex disodium salt dihydrate (Merck), acetic acid (Merck), and aquadest.

Collection and authentication of plant

M. calabura L. fruits were obtained from Bantul, Yogyakarta, Indonesia. M. calabura L. plant identification was carried out at the Laboratory of 
Pharmaceutical Biology, Faculty of Pharmacy, Gadjah Mada University Yogyakarta, with number: 18.2.9/UN1/FFA/BF/PT/2019.

\section{Animals}

Swiss mice (male, 20-30 g, 8-10 weeks old) were obtained from the Faculty of Pharmacy, Universitas Muhammadiyah Surakarta, Indonesia. The mice maintained with constant relative humidity (50-60\%), under constant temperature $\left(23-25^{\circ} \mathrm{C}\right)$, and controlled light (12 h light/dark). Mice were fed with standard rodent chow and "pure it" water ad libitum. Acclimatized mice were done for at least 7 days before the research.

The use of test animals in this research has been approved by the Ethics Commission of the Faculty of Medicine, Universitas Muhammadiyah Surakarta, with an ethical eligibility letter No: 2392/A.2/KEPK-FKUMS/ IX/2019.

\section{Extraction and fractionation of $M$. calabura L. fruits}

Fresh fruits of M. calabura L. were washed with water. The fruits were dried in the oven at $46^{\circ} \mathrm{C}$ for 7 days. The dried powder of $M$. calabura L. $(1.5 \mathrm{~kg})$ was macerated with $10.5 \mathrm{l}$ of methanol for 3 days. The filtrate was evaporated using a vacuum evaporator to obtain a viscous methanolic extract. Liquid-liquid partition using hexane was used to fractionate of ME to obtain hexane insoluble and soluble fraction. The hexane insoluble fraction was then fractionated with dichloromethane to yield dichloromethane soluble fraction. Furthermore, dichloromethane nonsoluble fraction was then fractionated with ethyl acetate to obtain ethyl acetate soluble fraction. All soluble fractions were then evaporated to get viscous fractions.

\section{Determination of total phenolic content}

Total phenolic content in the extracts and fractions of M. calabura L. was determined by visible spectrophotometry using the Folin-Ciocalteu reagent with some modification [12]. The standard curve was made with concentration series of $50,25,12.5,6.25$, and $3.125 \mathrm{ppm}$ then taken from this concentration series plus $0.5 \mathrm{ml}$ of Folin-Ciocalteu reagent $10 \%$ allowed to stand for $3 \mathrm{~min}$. Then added $2 \mathrm{ml}$ of $7.5 \%$ $\mathrm{Na}_{2} \mathrm{CO}_{3}$, incubated for $60 \mathrm{~min}$ and they were measured at a wavelength of $745 \mathrm{~nm}$.

One hundred milligrams of the sample were weighed then dissolved in $25 \mathrm{ml}$ methanol; sonification was performed for $15 \mathrm{~min}$. Taken $0.5 \mathrm{ml}$ solution plus $0.5 \mathrm{ml}$ of $10 \%$ Folin-Ciocalteu reagent, the mixture was allowed to stand for $3 \mathrm{~min}$, and $2 \mathrm{ml}$ of $7.5 \% \mathrm{Na}_{2} \mathrm{CO}_{3}$ was added in this solution and then was incubated for $15 \mathrm{~min}$ and its absorbance was measured at a wavelength of $745 \mathrm{~nm}$. The blank solution contained distilled water and Folin-Ciocalteu reagent. All measurements were carried out in triplicate. Total phenolic content was calculated in mg gallic acid equivalent of each $1 \mathrm{~g}$ extract or fraction.

\section{Determination of total flavonoid content}

Total flavonoid content in extracts and fractions of $M$. calabura L. was determined by visible spectrophotometry using the aluminum chloride $\left(\mathrm{AlCl}_{3}\right)$ method. This method refers to Saleem and Ahmad with some modifications $[13,14]$. The flavonoid content was calculated as a quercetin equivalent. Quercetin was made concentration series of $20,30,40,50$, and $60 \mathrm{ppm}$, then added $0.1 \mathrm{ml}$ of $10 \% \mathrm{AlCl}_{3}$ and $0.1 \mathrm{ml}$ sodium acetate $1 \mathrm{~m}$ and add methanol up to $5 \mathrm{ml}$, incubated for $30 \mathrm{~min}$ at room temperature, then they were measured at a wavelength of $431 \mathrm{~nm}$.

One hundred milligrams of sample were weighed then dissolved in $25 \mathrm{ml}$ methanol; this solution was taken $2 \mathrm{ml}$ then added $1.5 \mathrm{ml}$ aquadest. After that, it was added $0.1 \mathrm{ml} \mathrm{AlCl}_{3} 10 \%$ reagent and $0.1 \mathrm{ml}$ sodium acetate $1 \mathrm{~m}$. Aquadest was added until $5 \mathrm{ml}$ followed by incubation for $30 \mathrm{~min}$ at room temperature. Its absorbance was measured at a wavelength of $431 \mathrm{~nm}$. The blank solution contained only distilled water and $\mathrm{AlCl}_{3}$ reagent. All measurements were carried out in triplicate, and total flavonoid content was expressed in mg quercetin equivalent of each $1 \mathrm{~g}$ extract or fraction.
Test for immunomodulatory activity

The test was designed to evaluate the immunostimulating effect of ME of $M$. calabura L. and its fraction on non-specific immune response in normal mice.

Preparation of carbon colloidal suspension

Carbon suspension was made by suspending $1.6 \mathrm{ml}$ of Indian ink in $8.4 \mathrm{ml}$ of $1 \%$ gelatin (gelatin was dissolved in $0.9 \%$ pyrogen-free $\mathrm{NaCl}$ solution) [15].

\section{Carbon clearance test}

The effect of ME, hexane fraction (HF), dichloromethane fraction (DF), and ethyl acetate fraction (EAF) of M. calabura L. on reticuloendothelial (RES) cells in eliminating carbon particles was tested in vivo. Mice were grouped into 14 groups randomly, five mice in each group. Group 1 as a negative control was given tween 3\% in CMC Na $0.5 \%$; Group 2 was given Zymosan A at a dose of $15 \mathrm{mg} / \mathrm{kg}$ (positive control) intraperitoneally, and mice in Groups 3-5, 6-8, 9-11, and 12-14 were administered with the extract of ME 50, 100, and $200 \mathrm{mg} / \mathrm{kg}$; HF 50, 100 , and $200 \mathrm{mg} / \mathrm{kg}$; DF 50, 100, and $200 \mathrm{mg} / \mathrm{kg}$; and EAF 50, 100, and $200 \mathrm{mg} / \mathrm{kg}$, respectively, orally, daily for 7 consecutive days. On the $8^{\text {th }}$ day, the mice were injected $0.1 \mathrm{ml} / 10 \mathrm{~g}$ mice with a suspension of colloidal carbon in gelatin through veins in the tails. A total of $25 \mu$ l blood samples were taken through the tail vein before injection of carbon suspension (on minute 0 ) and at 5, 10, 15, 20, and $30 \mathrm{~min}$ after carbon injection. Blood samples were lysed with $1 \%$ acetic acid and percent of transmittance was read using a spectrophotometer at a wavelength of $675 \mathrm{~nm}$. Blood also was taken for leukocytes examination. After that the mice were sacrificed, the liver and spleen were isolated and weighed [16]. The organ index was calculated per body weight of each test animal multiplied by 100 [17].

\section{Data analysis}

All data (phagocytic index, organ index, leukocytes, total phenolic, and total flavonoid) were presented as mean \pm SEM (the standard error of the mean). The data were analyzed using one-way ANOVA followed by the least significant difference test with a confident level of $95 \%$

Phagocytic index $(\mathrm{k})$ or rate of carbon clearance was determined from the coefficient regression of each time-concentration (at the minutes: $5,10,15,20$, and 30$)$ curve drawn by plotting (100 - mean transmittance value) as ordinate against time as the abscissa [16]. Furthermore, the regression coefficient of treatment was compared to the regression coefficient of the negative control. According to Wagner, the phagocytic index between 1 and 1.5 indicates a moderate immunostimulation effect and phagocytic index $>1.5$ indicates a strong immunostimulation effect [18]. The percentage change of the phagocytic index from the control group was calculated by (phagocytic index of treatment group -1) $\times 100$.

\section{RESULTS}

The yield obtained from the extraction and fractionation of M. calabura L., namely, ME, HF, DF, and EAF was 30.30, 0.50, 0.59, and $1.49 \%$, respectively. The highest yield is ME, followed by EAF, and the least is non-polar HF. This shows that M. calabura L. fruit contains more polar and semipolar compounds than non-polar compounds.

The immunomodulatory activity of ME and its fraction of M. calabura L. are evaluated against non-specific immune responses that are innate immune systems, which means that responses to foreign substances can occur even though the body never been exposed to these substances before. The non-specific immune system functions to provide an early response to pathogens that enter the body.

The carbon clearance test method is carried out to observe the activity of the reticuloendothelial system (RES) in eliminating colloidal carbon suspension from blood circulation. Macrophages play an important role at all stages of the body's defense both in acquired and innate 
immunity. When the pathogen passes through the epithelial barrier, the pathogenic bacteria will be phagocytosed by macrophages and digested using lysosomal enzymes [16]. Carbon was used as a marker in this test because it has several advantages, such as the particle size is small and stable. Hence, carbon does not cause blockage of blood vessels and lungs. Carbon has characteristics as an antigen and in normal circumstances; it is not present in the body [19]. The phagocytic index is the rate of carbon clearance from the blood by macrophage ingested.

The effects of ME M. calabura L. and its fraction on the phagocytic index through the carbon clearance test are shown in Tables 1 and 2.

Table 1 shows that an increase in the value of transmittance starts from the $5^{\text {th }}$ min. In the positive control group (Zymosan A) and ME dose 50,100 , and $200 \mathrm{mg} / \mathrm{kg}$ showed an increase in transmittance values compared to the control group.

Oral administration of ME at a dose of $200 \mathrm{mg} / \mathrm{kg}$ and EAF of M. calabura L. 100 and $200 \mathrm{mg} / \mathrm{kg}$ for 7 days resulted in a significant increase in phagocytosis compare to the control group (Table 2). This indicates that there was an increase in phagocytic activity, whereas the HF showed a decrease in transmittance compared to control.

Table 2 shows that ME and EAF stimulate phagocytic activity as a response of non-specific immune response. Meanwhile, DF and HF at a dose of 100 and $200 \mathrm{mg} / \mathrm{kg}$ showed a significant decrease in a phagocytic index by the dose increase. ME with a dose of $200 \mathrm{mg} / \mathrm{kg}$ and ethyl acetate fraction of M. calabura L. fruits with a dose of 100 and $200 \mathrm{mg} / \mathrm{kg}$ show increasing of spleen weight [Table 3]

Although the liver is not classified as a primary or secondary lymphoid organ, the liver involves in the immune response because it contains fixed macrophages. The spleen is an important part of the RES which contains lymphocytes, monocytes, macrophages, and immune system cells such as dendritic cells, Langerhans, T cells, and $B$ cells [16]. The percentage of the liver index after administration of ME and EAF of M. calabura L. shows an increase even though there was no significant difference when compared with the control group. A significant difference $(p<0.05)$ was seen in the spleen index percent of the treatment group that was given ME $200 \mathrm{mg} / \mathrm{kg}$, DF $100 \mathrm{mg} / \mathrm{kg}$ extract, and EAF 100 and $200 \mathrm{mg} / \mathrm{kg}$ when compared to controls (Table 3). Increasing spleen weight indicates the proliferation of lymphocytes in the immune system, known as B cells and $\mathrm{T}$ cells.

Table 4 shows that there is no significant difference in the number of white blood cells (leukocytes) after administration extract and the fraction of $M$. calabura L. fruits for 7 days compare to the negative control group except at the HF of $M$. calabura L. at a dose of $200 \mathrm{mg} / \mathrm{kg}$. The HF group the dose of $200 \mathrm{mg} / \mathrm{kg}$ showed a decrease in the number of leukocytes, and when viewed from the phagocytic

Table 1: Transmittance value (\%) at 0 until 30 min after injection of carbon ink suspension

\begin{tabular}{|c|c|c|c|c|c|c|c|}
\hline \multirow[t]{2}{*}{ Treatment } & \multirow[t]{2}{*}{ Dose mg/kg } & \multicolumn{6}{|l|}{ At minute } \\
\hline & & 0 & 5 & 10 & 15 & 20 & 30 \\
\hline Control & 0 & $76.83 \pm 0.89$ & $36.07 \pm 0.43$ & $45.93 \pm 7.92$ & $49.70 \pm 7.85$ & $51.40 \pm 6.26$ & $55.97 \pm 6.59$ \\
\hline \multirow[t]{3}{*}{ ME } & 50 & $70.00 \pm 1.27$ & $37.43 \pm 7.09$ & $45.55 \pm 8.04$ & $42.67 \pm 7.01$ & $50.93 \pm 6.16$ & $60.97 \pm 6.23$ \\
\hline & 100 & $72.30 \pm 1.61$ & $30.60 \pm 3.91$ & $41.45 \pm 11.94$ & $46.65 \pm 13.23$ & $52.00 \pm 13.03$ & $57.73 \pm 14.10$ \\
\hline & 200 & $70.55 \pm 2.39$ & $26.23 \pm 7.84$ & $48.47 \pm 3.72$ & $50.50 \pm 11.68$ & $58.00 \pm 9.72$ & $64.60 \pm 9.14$ \\
\hline \multirow[t]{3}{*}{$\mathrm{HF}$} & 50 & $74.24 \pm 0.63$ & $30.80 \pm 4.38$ & $35.53 \pm 3.84$ & $42.26 \pm 6.02$ & $50.26 \pm 5.01$ & $53.90 \pm 5.97$ \\
\hline & 100 & $70.15 \pm 3.60$ & $30.75 \pm 6.32$ & $33.55 \pm 11.59$ & $34.28 \pm 6.16$ & $37.47 \pm 1.77$ & $46.47 \pm 8.05$ \\
\hline & 200 & $69.80 \pm 2.23$ & $31.03 \pm 6.56$ & $31.80 \pm 5.92$ & $36.65 \pm 4.51$ & $39.56 \pm 7.04$ & $47.46 \pm 8.37$ \\
\hline \multirow[t]{3}{*}{ DF } & 50 & $66.22 \pm 0.73$ & $42.18 \pm 2.15$ & $51.20 \pm 4.21$ & $53.46 \pm 3.58$ & $60.40 \pm 3.45$ & $63.10 \pm 2.55$ \\
\hline & 100 & $64.51 \pm 0.77$ & $47.04 \pm 1.92$ & $52.65 \pm 2.54$ & $63.10 \pm 2.94$ & $66.66 \pm 1.58$ & $69.56 \pm 1.20$ \\
\hline & 200 & $66.72 \pm 1.78$ & $53.48 \pm 1.48$ & $57.08 \pm 2.14$ & $57.83 \pm 6.50$ & $61.52 \pm 4.39$ & $61.85 \pm 0.26$ \\
\hline \multirow[t]{3}{*}{ EAF } & 50 & $73.75 \pm 1.07$ & $50.82 \pm 3.28$ & $56.74 \pm 3.63$ & $60.24 \pm 2.83$ & $65.97 \pm 3.30$ & $68.34 \pm 1.45$ \\
\hline & 100 & $67.04 \pm 0.48$ & $23.46 \pm 0.67$ & $35.72 \pm 2.36$ & $42.96 \pm 4.29$ & $46.10 \pm 3.05$ & $52.30 \pm 2.47$ \\
\hline & 200 & $73.15 \pm 1.57$ & $35.91 \pm 7.46$ & $42.95 \pm 2.80$ & $51.48 \pm 1.68$ & $58.37 \pm 7.86$ & $63.62 \pm 1.83$ \\
\hline
\end{tabular}

Minute 0 (baseline) is a transmittance value before intravenous carbon ink injection. ME, HF, DF, and EAF of M. calabura L. fruits. Each value represents the mean \pm SEM of five mice

Table 2: Effect of M. calabura L. extract and fraction on normal mice non-specific immune response

\begin{tabular}{lllll}
\hline Groups & Doses (mg/kg) & $\begin{array}{l}\text { Regression } \\
\text { coefficient (K) }\end{array}$ & $\begin{array}{l}\text { Correlation } \\
\text { coefficient (R) }\end{array}$ & $\begin{array}{l}\text { Phagocytic index } \\
\boldsymbol{k}_{\boldsymbol{t}}\end{array}$ \\
& & & $\begin{array}{l}\text { Phagocytic index change } \\
\text { from control (\%) }\end{array}$ \\
\hline Control & 0 & $-0.72 \pm 0.02$ & 0.86 & $1.00 \pm 0.03$ \\
Zymosan A & 15 & $-1.37 \pm 0.02^{*}$ & 0.90 & $1.90 \pm 0.02^{*}$ \\
ME & 50 & $-0.89 \pm 0.14$ & 0.91 & $1.23 \pm 0.20$ \\
& 100 & $-1.04 \pm 0.37$ & 0.92 & $1.44 \pm 0.51$ \\
HF & 200 & $-1.37 \pm 0.25^{*}$ & 0.83 & $1.90 \pm 0.35^{*}$ \\
& 50 & $-0.98 \pm 0.16$ & 0.92 & $1.35 \pm 0.23$ \\
DF & 100 & $-0.70 \pm 0.16$ & 0.92 & $0.97 \pm 0.22$ \\
& 200 & $-0.69 \pm 0.20$ & 0.98 & $0.95 \pm 0.28$ \\
& 50 & $-0.81 \pm 0.15$ & 0.90 & $1.12 \pm 0.20$ \\
EAF & 100 & $-0.93 \pm 0.08$ & 0.87 & $1.29 \pm 0.12$ \\
& 200 & $-0.33 \pm 0.02$ & 0.86 & $0.46 \pm 0.03$ \\
& 50 & $-0.71 \pm 0.04$ & 0.92 & -2.83 \\
& 100 & $-1.08 \pm 0.09$ & 0.89 & $0.98 \pm 0.06$ \\
\end{tabular}

ME: Methanol extract, HF: Hexane fraction, DF: Dichloromethane fraction, EAF: Ethyl acetate fraction of $M$. calabura L. fruits. $K$ is a slope of the treatment group, $K$ is a slope of a control group. Each value represents the mean \pm SEM of five mice. Statistically significant difference: ${ }^{*}$ p $<0.05$ as compared to control; phagocytic index between 1 and 1.5 indicates a moderate immunostimulation effect and $>1.5$ indicates a strong immunostimulation effect [18] 
index, the $\mathrm{HF}$ at a dose $200 \mathrm{mg} / \mathrm{kg}$ did not show an immunostimulant effect (Table 2)

\section{Total phenolic and flavonoid content}

The total phenolic content of the extract and fraction of M. calabura L. fruits was estimated using Folin-Ciocalteu reagent. Meanwhile, total flavonoid content was estimated using a method based on complex formation between flavonoid and $\mathrm{AlCl}_{3}$ that producing a yellow colored solution. Total phenolic contents are expressed in mg of gallic acid equivalent per g sample (Fig. 1)

Total phenolic content from the highest to the lowest is EAF, ME, DF, and HF. Meanwhile, total flavonoid levels are expressed in mg of quercetin equivalent per gram sample (Fig. 2). Total flavonoid levels from the highest to the lowest are ME, DF, EAF, and HF. The analysis statistic shows that there are significant differences in the total flavonoid and

Table 3: Body weight of mice and organ index after treatment extract and fraction of M. calabura L. fruits

\begin{tabular}{|c|c|c|c|c|c|c|}
\hline \multirow[t]{2}{*}{ Groups } & \multirow[t]{2}{*}{ Doses (mg/kg) } & \multirow[t]{2}{*}{ Body weight (g) } & \multirow[t]{2}{*}{ Weight of liver (g) } & \multirow[t]{2}{*}{ Weight of spleen (g) } & \multicolumn{2}{|c|}{ Organ index } \\
\hline & & & & & Liver (\%) & Spleen (\%) \\
\hline Control & 0 & $26.95 \pm 2.11$ & $1.230 \pm 0.11$ & $0.122 \pm 0.01$ & $4.55 \pm 0.36$ & $0.45 \pm 0.04$ \\
\hline \multirow[t]{3}{*}{ ME } & 50 & $26.72 \pm 2.61$ & $1.265 \pm 0.09$ & $0.088 \pm 0.01$ & $4.71 \pm 0.60$ & $0.34 \pm 0.05$ \\
\hline & 100 & $33.25 \pm 1.54$ & $1.564 \pm 0.18$ & $0.155 \pm 0.01$ & $4.70 \pm 0.11$ & $0.47 \pm 0.06$ \\
\hline & 200 & $26.90 \pm 2.54$ & $1.334 \pm 0.14$ & $0.151 \pm 0.01$ & $4.95 \pm 0.18$ & $0.66 \pm 0.04^{*}$ \\
\hline \multirow[t]{3}{*}{$\mathrm{HF}$} & 50 & $32.78 \pm 1.75$ & $1.573 \pm 0.07$ & $0.161 \pm 0.02$ & $4.81 \pm 0.17$ & $0.49 \pm 0.06$ \\
\hline & 100 & $29.90 \pm 1.34$ & $1.301 \pm 0.07$ & $0.146 \pm 0.02$ & $4.38 \pm 0.60$ & $0.48 \pm 0.07$ \\
\hline & 200 & $31.66 \pm 1.37$ & $1.389 \pm 0.06$ & $0.116 \pm 0.01$ & $4.42 \pm 0.65$ & $0.37 \pm 0.04$ \\
\hline \multirow[t]{3}{*}{ DF } & 50 & $32.48 \pm 2.55$ & $1.428 \pm 0.17$ & $0.114 \pm 0.02$ & $4.40 \pm 0.47$ & $0.41 \pm 0.09$ \\
\hline & 100 & $31.05 \pm 1.24$ & $1.328 \pm 0.05$ & $0.180 \pm 0.01$ & $4.28 \pm 0.55$ & $0.69 \pm 0.09 *$ \\
\hline & 200 & $32.48 \pm 0.54$ & $1.342 \pm 0.12$ & $0.132 \pm 0.02$ & $4.13 \pm 0.85$ & $0.48 \pm 0.16$ \\
\hline \multirow[t]{3}{*}{ EAF } & 50 & $30.03 \pm 0.67$ & $1.531 \pm 0.09$ & $0.151 \pm 0.01$ & $5.09 \pm 0.55$ & $0.59 \pm 0.11$ \\
\hline & 100 & $28.44 \pm 2.97$ & $1.566 \pm 0.18$ & $0.154 \pm 0.02$ & $5.48 \pm 0.24$ & $0.65 \pm 0.14^{*}$ \\
\hline & 200 & $27.52 \pm 1.10$ & $1.412 \pm 0.12$ & $0.149 \pm 0.01$ & $5.13 \pm 0.91$ & $0.64 \pm 0.14^{*}$ \\
\hline
\end{tabular}

ME: Methanol extract, HF: Hexane fraction, DF: Dichloromethane fraction, EAF: Ethyl acetate fraction M. calabura L. fruits. Each value represents the mean \pm SEM of

5 mice. Statistically significant difference: $* \mathrm{p}<0.05$ as compared to control

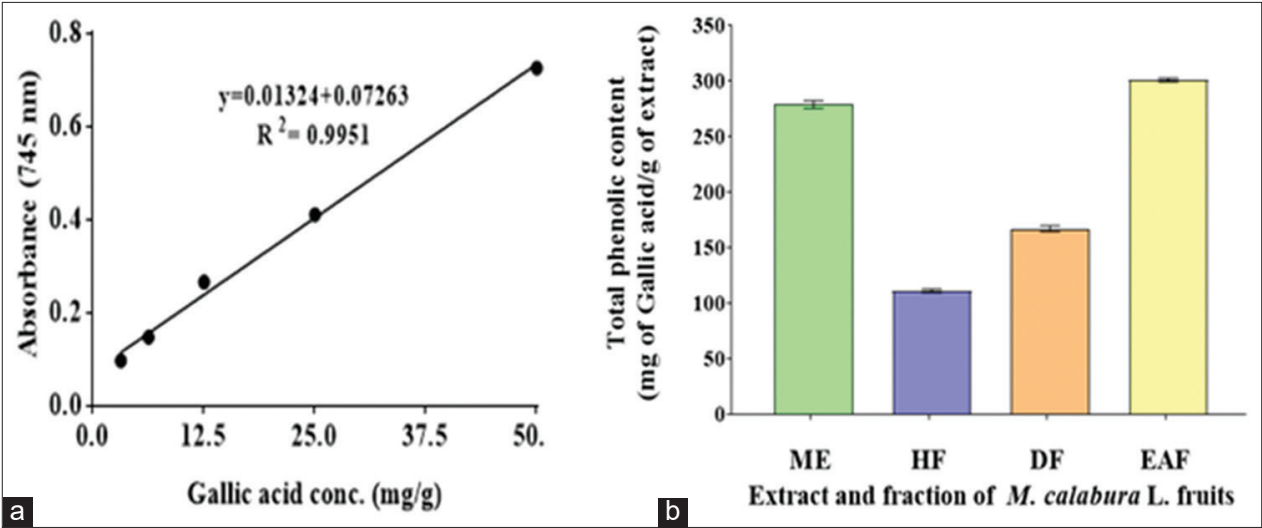

Fig. 1: (a) Linear curve gallic acid concentration (mg/g) versus absorbance for determination of total phenolic content (b) total phenolic content of methanol extract, hexane fraction, dichloromethane fraction, ethyl acetate fraction of Muntingia calabura L. fruits expressed in terms of gallic acid equivalent. Each value represents the mean \pm SEM of three replications
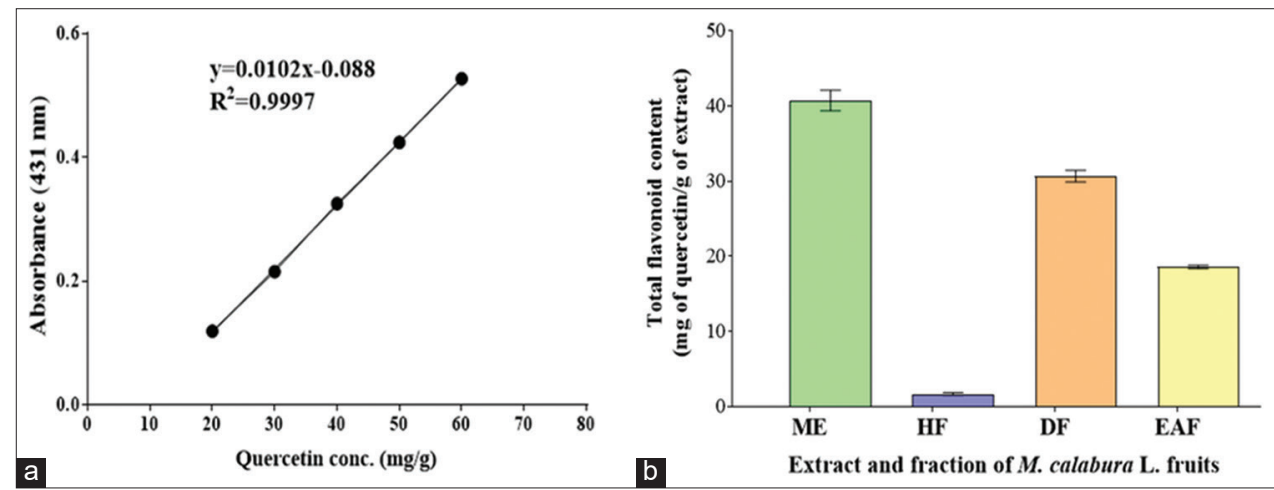

Fig. 2: (a) Linear curve quercetin concentration ( $\mathrm{mg} / \mathrm{g}$ ) versus absorbance for determination of total flavonoid content (b) total flavonoid content of methanol extract, hexane fraction, dichloromethane fraction, ethyl acetate fraction of Muntingia calabura L. fruits expressed in terms of quercetin equivalent. Each value represents the mean $\pm S E M$ of three replications 
Table 4: The number of leukocytes after administration of extract and fraction of $M$. calabura L. fruits for $\mathbf{7}$ days

\begin{tabular}{lll}
\hline Groups & Doses $(\mathbf{m g} / \mathbf{k g})$ & Leukocytes $\left(\mathbf{1 0}^{\mathbf{3}} \mathbf{/ u l}\right)$ \\
\hline Control & 0 & $9.41 \pm 1.28$ \\
Zymosan A & 15 & $7.64 \pm 3.23$ \\
Methanol extract & 50 & $8.67 \pm 2.97$ \\
& 100 & $7.08 \pm 2.66$ \\
$\mathrm{HF}$ & 200 & $7.34 \pm 2.56$ \\
& 50 & $8.93 \pm 0.52$ \\
& 100 & $8.45 \pm 2.91$ \\
Dichloromethane & 200 & $5.68 \pm 1.46^{*}$ \\
fraction & 50 & $9.30 \pm 2.39$ \\
& 100 & $10.64 \pm 2.94$ \\
Ethyl acetate fraction & 500 & $9.19 \pm 2.39$ \\
& 100 & $8.33 \pm 2.28$ \\
& 200 & $9.65 \pm 0.98$ \\
\end{tabular}

Each value represents the mean \pm SEM of 5 mice. Statistically significant difference: ${ }^{*} \mathrm{p}<0.05$ as compared to control

total phenolic content of the samples $(\mathrm{p}<0.05)$. Based on Fig. 1, the total phenolic content in these fractions varied widely. The total phenolic content depends on the polarity of the solvent.

Fig. 1 indicates that ME and EAF of M. calabura L. fruits contain more phenolic content than other fractions, so the phagocytic index increase. Reportedly, some polyphenols exhibit immunomodulatory activities [20]. Flavonoids are the main constituents of secondary metabolites in M. calabura L. [21].

\section{DISCUSSION}

The value of the phagocytic index was determined from the coefficient regression of the treatment group was compared to the regression coefficient of the negative control. A phagocytic index $>1$ indicates that the substance has an immunostimulation effect [18]. Zymosan A was used as a positive control because Zymosan A has provided as a model for recognition of microbes by the innate immune response for more 50 years including activation of complement mechanism of phagocytosis, and stimulation for inflammatory cytokine [22]. Table 2 shows that Zymosan A (positive control) has immunostimulant effects; this is in accordance with the previous studies that Zymosan A has an immunostimulant effect with phagocytic index value 1.28 [15,16].

In this research, the results showed that at the same doses $(50,100$, and $200 \mathrm{mg} / \mathrm{kg}$ ) the methanolic extract of M. calabura L had higher phagocytic index (1.23-1.90) than HF (1.35-0.95), DF (1.12-0.46), and EAF (0.98-1.57) in normal mice. The phagocytic index values show that the ME (polar extract) has a greater immunostimulant effect than the EAF (semipolar). Meanwhile, HF (non-polar) and DF (relatively non-polar) show that the greater the dose, the immunomodulatory effect decreases. This is in line with Trihastuty research that the greater the dose of the extract of petroleum ether (non-polar), the phagocytic index decreases and shows immunosuppressant effects (phagocytic index $<1$ ), due to the presence of immunosuppressant substance such as terpenoids [22]. Besides carbohydrates, phenolic and flavonoid compounds, M. calabura L. fruits also contain terpenoids [23]. An increase in the carbon clearance index indicates the enhancement of the macrophage function in phagocytosis and non-specific immunity [24].

Fig. 2 shows that although dichloromethane fraction (DF) of M. calabura L. has total flavonoid (quercetin equivalent) more than EAF but the phagocytic index of DF lower than EAF. This is possible because flavonoids in this fraction may be different that resulting in different activities even decrease the phagocytic index in dichloromethane dose $200 \mathrm{mg} / \mathrm{kg}$. Other studies have shown that although daidzein and genistein are a group of flavonoids in the form of isoflavones, their effects are the opposite in their immunomodulatory activity [25]. Dichloromethane extract of $M$. calabura fruits contains squalene, triglyceride, a mixture of linoleic acid, palmitic acid, and $a$-linolenic acid and a mixture of $\beta$-sitosterol and stigmasterol [26]. The flavonoid content in the ME of M. calabura L. fruits is thought to be responsible for its immunomodulatory activity. The previous studies have shown that MEs from roots, fruits, leaves, and the bark of M. calabura L. contain various flavonoids of flavan and flavon groups [27]. MEs of leaf, bark, and fruits M. calabura L. revealed the presence of glycoside and flavonoid as a major biologically active compound [28]. In many researches show that in vitro tests flavonoids show a relatively high immunomodulatory activity, but when tested in vivo, sometimes the immunomodulatory effect is low, this is because the solubility of flavonoids in water is low even in the form of glycosides. The mechanism of absorption of flavonoids in the gastrointestinal system causes a number of flavonoids to be absorbed in the small intestine $[29,30]$.

\section{CONCLUSION}

The ME and EAF of M. calabura L. have immunostimulatory activity by stimulating the nonspecific immune response. The total phenolic content of ME, HF, DF, and EAF was 27.9, 11.11, 16.72, and 30.11\%, respectively, while the flavonoid contents were 4.07, 0.17, 3.07, and $1.86 \%$, respectively.

\section{ACKNOWLEDGMENT}

We would like to acknowledge financial support from The Ministry of Research, Technology and Higher Education of Indonesia for research funding PDUPT 2019.

\section{AUTHORS' CONTRIBUTIONS}

All authors were involved in data collection and worked to do this manuscript. Mrs. Ika analyzed the data, Mrs. Tanti wrote the first draft and final manuscript, and Mrs. Rima edited the manuscript.

\section{CONFLICTS OF INTEREST}

All authors declare that they have no conflicts of interests.

\section{REFERENCES}

1. Mahima, Ingle AM, Verma AK, Tiwari R, Karthik K, Chakraborty S, et al. Immunomodulators in day to day life: A review. Pak J Biol Sci 2013;16:826-43.

2. Jantan I, Ahmad W, Bukhari SN. Plant-derived immunomodulators: An insight on their preclinical evaluation and clinical trials. Front Plant Sci 2015;6:655

3. Preethi K, Premasudha P, Keerthana K. Anti-inflammatory activity of Muntingia calabura fruits. Pharmacogn J 2012;4:51-6.

4. Pramono VJ, Santoso R. Pengaruh ekstrak buah kersen (Muntingia calabura) terhadap kadar gula darah tikus putih (Rattus norvegicus) yang diinduksi streptozotocin (STZ). J Sain Vet 2014;32:218-23.

5. Sarimanah J, Adnyana IK, Sukandar EY, Kurniati NF. The antirheumatic activity of Muntingia calabura L. Leaves ethanol extract and its fraction. Asian J Pharm Clin Res 2017;10:84-6.

6. Siddiqua A, Premakumari KB, Sultana R, Vithya, Savitha. Antioxidant activity and estimation of total phenolic content of Muntingia calabura by colorimetry. Int J Chem Technol Res 2010;2:205-8.

7. Prakosa AP. Imunomodulasi Ekstrak Buah Talok (Muntingia calabura Linn) Terhadap Makrofag Peritoneum Tikus Wistar Jantan yang Diinduksi Actinobacillus Actionycetemcomitans. Indonesia: Universitas Jendral Soedirman; 2014.

8. Kalaskar MG, Surana SJ. Free radical scavenging, immunomodulatory activity and chemical composition of Luffa acutangula Var. Amara (Cucurbitaceae) pericarp. J Chil Chem Soc 2014;59:2299-302.

9. Patel S, Vajdy M. Induction of cellular and molecular immunomodulatory pathways by Vitamin A and flavonoids. Expert Opin Biol Ther 2015;15:1411-28.

10. Grigore A. Plant phenolic compounds as immunomodulatory agent. In: Phenolic Compound-Biological Activity. London: Intech Open; 2017. p. $75-88$.

11. Ganeshpurkar A, Saluja AK. Experimental animal models used for evaluation of potential immunomodulators: A mini review. Bull Fac Pharmacy Cairo Univ 2017;55:211-6.

12. Chun OK, Kim DO, Lee CY. Superoxide radical scavenging activity 
of the major polyphenols in fresh plums. J Agric Food Chem 2003;51:8067-72.

13. Saleem M, Maqbool M, Musadiq H, Ahmad S, Hassan A, Ahmad S. Pathomorphological effects of alloxan induced acute hypoglycaemia in rabbits. Alex J Med 2013;49:343-53

14. Ahmad AR, Sakinah, Wisdawati, Asrifa WO. Study of antioxidant activity and determination of phenol and flavonoid content of pepino's leaf extract (Solanum muricatum Aiton). Int J Pharm Technol Res 2014;6:600-6.

15. Faradilla M, Iwo MI. Efck imunomodulator polisakarida rimpang temu putih immunomodulatory effect of polysaccharide from white turmeric [Curcuma zedoaria (Christm) Roscoe)] rhizome. J Ilmu Kefarmasian Indones 2014;12:273-8.

16. Iwo MI, Soemardji AA, Retnoningrum DS, Sukrasno, U UM. Immunostimulating effect of pule (Alstonia scholaris L. R.Br., Apocynaceae) bark extracts. Clin Hemorheol Microcirc 2000;23:177-83.

17. Shrestha P, Handral M. Evaluation of immunomodulatory activity of extract from rind of Nephelium lappaceum fruit. Int J Pharm Pharm Sci 2016;9:38-43

18. Wagner H, Kraus S, Jurcic K. Search for Potent Immunostimulating Agents from Plants and Other Natural Sources. Immunomodulatory Agents from Plants. Berlin, Germany: Springer; 1999. p. 1-39.

19. Dillasamola D, Aldi Y, Fakhri M, Diliarosta S, Oktomalio PB, Noverial N. Immunomodulatory effect test from moringa leaf extract (Moringa oleifera L.) with carbon clearance method in male white mice. Asian J Pharm Clin Res 2018;11:241-5.

20. Ghiringhelli F, Rebe C, Hichami A, Delmas D. Immunomodulation and anti-inflammatory roles of polyphenols as anticancer agents. Anticancer Agents Med Chem 2012;12:852-73.

21. Putri DA, Fatmawati S. Metabolit sekunder dari Muntingia calabura dan bioaktivitasnya. Alchemy J Penelit Kim 2019;15:57.

22. Underhill DM. Macrophage recognition of zymosan particles. J Endotoxin Res 2003;9:176-80.

23. Pereira GA, Arruda HS, de Morais DR, Eberlin MN, Pastore GM. Carbohydrates, volatile and phenolic compounds composition, and antioxidant activity of calabura (Muntingia calabura L.) fruit. Food Res Int 2018;108:264-73.

24. Wagle N, Nagarjuna S, Sudheer A, Roopesh C, Sapkota HP, Dangi NB, et al. Evaluation of immunomodulatory activity of petroleum ether extract of seeds of Pithecellobium dulce in wistar rats. Int J Pharm Pharm Sci 2015;7:471-9.

25. Maji AK, Mahapatra S, Banerjee D. In vivo immunomodulatory potential of standardized Pueraria tuberosa extract and its isoflavonoids. Int J Pharm Pharm Sci 2014;6:861-7.

26. Ragasa CY, Tan MC, Chiong ID, Shen CC. Chemical constituents of Muntingia calabura L. Pharma Chem 2015;7:136-41.

27. Mahmood ND, Nasir NL, Rofiee MS, Tohid SF, Ching SM, Teh LK, et al. Muntingia calabura: A review of its traditional uses, chemical properties, and pharmacological observations. Pharm Biol 2014;52:1598-623

28. Sibi G, Naveen R, Dhananjaya K, Ravikumar KR, Mallesha H. Potential use of Muntingia calabura L. Extracts against human and plant pathogens. Pharmacogn J 2012;4:44-7.

29. Bilia AR, Isacchi B, Righeschi C, Guccione C, Bergonzi MC. Flavonoids loaded in nanocarriers: An opportunity to increase oral bioavailability and bioefficacy. Food Nutr Sci 2014;5:1212-27.

30. Pratiwi G, Martien R, Murwanti R. Chitosan nanoparticle as a delivery system for polyphenols from meniran extract (Phyllanthus niruri L.): Formulation, optimization, and immunomodulatory activity. Int J Appl Pharm 2019;11:50-8 